\title{
de CHequebank.
}

Wanneer men het geheele bedrag bankpapier en muntbilletten, dat in Nederland en aangrenzende landen in omloop is, deelt door het aantal inwoners, dan vindt men per hoofd:

$\begin{array}{llcccc}\text { in Engeland } & \text { een bedrag van circa } f & 15 \\ n \text { Schotland } & n & n & " & \# & 18 \\ n \text { Ierland } & n & n & " & n & 15 \\ n \text { Duitschland } & n & n & n & n & 14 \\ " \text { Frankrijk } & n & n & n & n & 30 \\ " \text { Belgie } & n & n & n & n & 30 \\ n \text { Nederland } & n & n & n & n & 55\end{array}$

Het oog wordt bij vergelijking dadelijk getroffen door het groote verschil tusschen Nederland on al de andere landen, en men vraagt zich af wat de oorzaak is van dit verschijnsel. Gedeeltelijk is het zeker toe te schrijven aan het groote vertier in Nederland, dat veel circulatiemiddel noodig maakt, maar het verschil met Engeland althans wordt hierdoor niet verklaard; voornamelijk moet hiervan de oorzaak gezocht worden in het weinige gebruik, dat hier te lande nog van cheqnes wordt gemaakt. Het gebruik van cheques als betaalmiddel, dat neêrkomt op eene uitwisseling van vorderingen, levert drie groote voordeelen op:

Besparing van ruilmiddel (bankbilletten, muntbilletten en specie) waardoor kapitaal dat anders renteloos daarin vastgelegd zou blijven, aan de productie weêrgegeven wordt.

Vermindering van risico, daar cheques veel minder gevaar van verloren gaan of diefstal opleveren dan specie en bankpapier.

Gemak in het afpassen van onevene bedragen..

Dat de cheques hier te lande over het algemeen nog geen burgerrecht verkregen hebben is waarschijnlijk hoofdzakelijk te wijten aan het gevaar aan het aannemen van cheques verbonden, namelijk het crediet den afgever te verleenen, daar de botaling van een cheque afhangt van het creditsaldo van den trekker. 
Men kan den duur van dit crediet zeer beperken door onmiddellijke incasseering, maar bezorgt zich dan den last den cheque zelf te moeten gaan ontvangen, zonder hem aan derden in betaling te kunnen geven. Het schijnt mij daarom niet onbelangrijk nader kennis te maken met eene Engelsche inrichting, die dit bezwaar voor een gedeelte der benoodigde cheques opheft.

In het jaar 1873 is in Londen eene bank opgericht, die op eene nieuwe wijze in de behoefte aan circulatie-middel van klein bedrag tracht te voorzien. Het hoofddenkbeeld dat aan de Bank ten grondslag ligt, is de wenschelijkheid kleine betalingen te kunnen verrichten met cheques voor afgepaste bedragen, die door iedereen zonder eenig risico kunnen aangenomen worden, daar hunne betaling, onafhankelijk van het saldo en het crediet van den trekker, volkomen zeker is. Dit doel bereikt zij door ehequeformulieren te verschaffen, waarop het maximum bedrag, waarvoor zij gebruikt kunnen worden, gedrukt staat, en deze formulieren niet anders dan tegen vooruitbetaling van dat bedrag af te geven. Daar de Chequebank dus voor elken cheque, die in omloop is, uit den aard der zaak dekking in handen heeft; $d$ :ar zij geene andere zaken doet, hare fondsen op zeer soliede wijze uitzet en een garantiekapitaal bezit, ten name van derden belegd, zijn de cheques in zekerheid gelijk aan promesses van een zeer soliede bank. Door deze vernuftige uitvinding van den heer James Hertz (thans Managing Director der Chequebank) is dus het systeem van betaalmiddelen van Engeland verrijkt met papier, betaalbaar op vertoon, van ieder gewenscht bedrag onder $10 \mathrm{pd}$. st., dat algemeen, zelfs door telegraaf- en spoorwegmaatschappijen, dokken, douaneen zegelbureaus aangenomen wordt, veel minder gevaar voor diefstal oplevert dan bankbilletten en over de geheele wereld kan geïncasseerd of verkocht worden.

De chequeformulieren zijn aan de voorzijde met het maximum bedrag, waarvoor zij kunnen dienen, gestempeld en doorgeslagen. Zij zijn aan order getrokken en moeten dus op de achterzijde afgeteekend worden; bovendien zijn ze "crossed" en worden dus alleen aan bankiers betaald; twee maatregelen, waardoor diefstal bemoeielijkt wordt. Op de achterzijde zijn de volgende bepalingen gedrukt:

1. Geen chequeformulier wordt door de chequebank afgegeven, eer het volle bedrag, op de voorzijde gestempeld, betaald is. $E r$ kan dus nooit gedispon"erd worden zonder dat dekking aanwezig is.

2. Geen cheque uitgeschreven voor een hooger bedrag dan op 
de voorzijde gestempeld is, zal door de Bank betaald worden, maar cen cheque kan voor ieder kleiner bedrag worden uitgeschreven.

3. Het hoogste bedrag, waarvoor een cheque kan getrokken worden, is $10 \mathrm{pd}$. st.

4. Het bedrag van een uitgeschreven cheque kan nooit gedisponeerd worden eer de cheque ter betaling is voorgekomen, hoe lang hij ook in omloop moge blijven.

5. De Chequebank deponeert al het geld, dat zij ontvangt, bij de Bank of England en de andere banken in de openbaar gemaakte lijsten vermeld.

Buitendien moet volgens de statuten steeds een belegd garantiefonds ton name van gemachtigden (trustees) gevestigd blijven.

De chequeformulieren worden uitgegeven in boekjes van tien on voor bedragen van $1,2,3$ tot 10 pond, hetzij van één soort of van verschillende soorten gesorteerd. De kosten bedragen 1 shilling voor ieder boekje, behalve 5 shilling per jaar per rekening. Nauwkeurige invulling der souches is verplichtend.

Over het verschil tusschen de bedragen voor de chequeformulieren betaald en de bedragen waarvoor zij ingevuld zijn bij de afgifte der cheques, kan beschikt worden in contanten of worden desverkiezend nieuwe cheques verstrekt.

De Bank verkoopt ook enkele cheques voor remise per post tot ieder gewenscht bedrag onder $10 \mathrm{pd}$. st. tegen eene vergoeding van 2 à 8 pence. $Z i j$ heeft voor dit doel 444 agenten aangesteld, terwijl 560 bankiers in Groot-Brittanje stortingen voor haar in ontvangst nemen en chequeboekjes verkoopen en 766 banken in het buitenland zich bereid hebben verklaard de cheques te koopen. De bedragen door hare correspondenten tegen verkoop van chequeboekjes ontvangen, laat zij bij henzelven à deposito. Op deze wijzo staan de deposito's door haar ontvangen gedeeltelijk uit bij een groot aantal der beste banken en zijn steeds beschikbaar, terwijl haar risico op deze tijdelijke geldbelegging zeer verdeeld is. Het garantiefonds is belegd in effecten van eerste soliditeit.

De voordeelen voor het publiek bestaan in de eerste plaats in het gemak kleine bedragen met cheque te kunnen afpassen, en chequeboekjes zonder vrees voor misbruik aan ondergeschikte personen te kunnen toevertrouwen. Een ruim gebruik op deze wijze wordt echter verhinderd door de zegelwet, die 1 penny per cheque eischt, eene belasting, die bij bedragen van een of een paar pond sterling zwaar drukt, en daarvoor de voorkeur aan goud en zilver doet geven. Het grootste debiet vinden deze 
cheques tot nu toe in plaats van postwissels; zij zijn niettegenstaande het zegel goodkooper en tevons gemakkelijker, daar men niet om ze te koopen of te ontvangen naar het postkantoor behoeft to gaan, maar ze te huis kan uitschrijven en verzenden of bij ontvangst aan ieder in betaling geven.

De inkomsten der Bank bestaan uit:

1. Rente van haar kapitaal en garantiefonds.

2. Commissie van 5 shilling per rekening per jaar.

3. $n 1 n$ minus 10 pence zegel $=2$ pence per chequeboekje.

4. Rente op haar deposito's, hoofdzakelijk bestaande uit het bedrag van verkochte maar nog niet opgekomen cheques. Over deze bedragen vergoedt de Bank geen rente, maar trekt er rente van à deposito bij andere banken of door belegging in fondsen. Het bedrag dezer rentelooze deposito's hangt af van

(a) het tijdsverloop eer een chequcformulier gebruikt wordt.

(b) het tijdsverloop gedurende hetwelk een cheque in omloop is.

(c) het verschil tusschen het maximum en het effectief bedrag der cheques.

De omloopstijd is nog niet lang, daar de algemeene goede gewoonte cheques dadelijk te incasseeren teneinde het regresrecht tegen de trekkers to behouden ook onnoodig op deze vooruitbetaalde cheques wordt toegepast; het is daardoor in het belang der Bank, dat de cheques meer en meer in plaats van binnenen buitenlandsche postwissels en als reiswissels gebruikt worden.

Tegenover de inkomsten staan de administratiekosten en de rente à $5 \mathrm{pCt}$. van het garantie-kapitaal, waartegen obligaties afgegeven zijn. Tot nu toe zijn deze uitgaven meer geweest dan de inkomsten en de Winst- en Verliesrekening over 1877-8 toont tegen Inkomsten. . . . 5317 ${ }_{9}^{2}$ pd. st. vitgaven . . . . . $\cdot \frac{86622_{\mathrm{s}}^{8}}{3345^{5}}{ }_{\text {verlies overblijft }}^{\text {pan }}$,

zoodat een verlies overblijft van ..$\overline{3345 \frac{5}{4}} \overline{\text { pd. }}$ st. waarop de bizonder lage rentestandaard in 1877 natuurlijk zeer nadeelig gewerkt heeft.

Het kapitaal bedraagt nominaal . . . 53,320 pd. st.

$$
\text { Hierop zijn gestort . . 21,328 " }
$$

Het garantiefonds bedraagt. . . . 27,000 n

De omzet over $1877-78$ was . . . 833,300 " verdeeld in 308,996 cheques en zal circa mocten verdubbelen eer 
een dividend an de aandeelhouders kan uitgrekcerd worden. Er is dus nog een tijd van ontwikkeling noodig eer de Chequebank een gezond leven kan leiden, maar zij gaat in den laatsten tijd goed vooruit en het is opmerkenswaardig, dat terwijl de Staat door de uitbreiding van het postwisselverkeer voortdurend schade geleden heeft, de Chequebank, die minder onkosten berekent, meer gemak aanbiedt en zegel aan den Staat betaalt, bij uitbreiding van het gebruik harer cheques als postwissels voordeel heeft. Wanneer ooit het pennyzegel op zicht cheques afgeschaft werd!, zou de Chequebank eene groote vlucht kunnen nemen en eene aanzienlijke besparing van metalen ruilmiddel kunnen veroorzaken.

Voor remise bestaat in Nederland aan dergelijke cheques minder behoefte, daar de onkosten van postwissels hier slechts $0.40 \mathrm{pCt}$. tegen 0.83 à $0.50 \mathrm{pCt}$. in Engeland bedragen en hun gebruik minder lastig is dan daar. Daarentegen zouden zij als betaalmiddel in den vorm van ongezegelde assignaties misschien veel gemak en besparing van ruilmiddel kunnen opleveren, en hier wel met bankpapier en specie maar weinig met gewone cheques te concurreeren hebben. Voor het betalen van huishoudelijke en particulicre rekeningen en quitanties, kantoor-onkosten, vrachten, loonen, honorariums, contributies, telegrammen, plaatsbilletten enz. zouden zij een groote aanwinst zijn. Het zou de vraag wezen of goedkeuring der statuten eener Chequebank in Nederland zou verkregen worden. $\mathrm{Zij}$ is in haar aard een circulatiebank maar mist het kenmerk eener circulatiebank, door de bankwet aangegeven, namelijk het uitgeven of in omloop brengen van bankbilletten. Hare cheques zouden niet als zoodanig kunnen beschouwd worden, eerstens wegens den vorm, en ten tweede daar $z i j$ aan order worden getrokken, en dus (tenzij in blanco afgeteekend) niet aan toonder betaalbaar zouden zijn. In Engeland is de rechtsgeldigheid, schoon niet zonder tegenstand, buiten twijfel gesteld. Het blijft intusschen zeer onzeker of eene Nederlandsche Chequebank, zelfs na verloop van jaren, voldoenden omzet zou hebben om de administratiekosten te dekken en dividend te geven. De stroom is echter in dien geest; naarmate de natiön in ontwikkeling vooruit gaan, worden goud en zilver door inwisselbaar papiergeld vervangen on wordt het gebruik van papiergeld door cheques en overdrachten beperkt. De ontwikkeling dezer betaalmiddelen is tevens de beste remedie tegen de schaarschte aan goud, die ontstaat door de uitdrijving van zilver uit de Europeesche muntstelsels.

P. H. de Cherce. 